\title{
Performance management, vigour, and training and development as predictors of job satisfaction in low- income workers
}

\begin{tabular}{|c|c|}
\hline \multicolumn{2}{|c|}{$\begin{array}{l}\text { Authors: } \\
\text { Molefe J. Maleka }{ }^{1} \text { (D) } \\
\text { Leigh-Anne Paul-Dachapalli2 }^{2} \\
\text { Suzette C. Ragadu }{ }^{1} \text { (D) } \\
\text { Cecilia M. Schultz }{ }^{2} \text { (D) } \\
\text { Lize van Hoek }^{2} \text { (D) }\end{array}$} \\
\hline \multicolumn{2}{|c|}{$\begin{array}{l}{ }^{1} \text { Department of People } \\
\text { Management and } \\
\text { Development, Faculty } \\
\text { of Management Science } \\
\text { Tshwane University of } \\
\text { Technology, eMalahleni } \\
\text { Campus, eMalahleni, } \\
\text { Pretoria, South Africa }\end{array}$} \\
\hline \multicolumn{2}{|c|}{$\begin{array}{l}{ }^{2} \text { Department of People } \\
\text { Management and } \\
\text { Development, Faculty of } \\
\text { Management Sciences, } \\
\text { Tshwane University of } \\
\text { Technology, Pretoria Campus, } \\
\text { Pretoria, South Africa }\end{array}$} \\
\hline \multicolumn{2}{|c|}{$\begin{array}{l}\text { Corresponding author: } \\
\text { Molefe Maleka, } \\
\text { malekam@tut.ac.za }\end{array}$} \\
\hline \multicolumn{2}{|c|}{$\begin{array}{l}\text { Received: } 23 \text { July } 2019 \\
\text { Accepted: } 27 \text { Nov. } 2019 \\
\text { Published: } 18 \text { May } 2020\end{array}$} \\
\hline \multicolumn{2}{|c|}{$\begin{array}{l}\text { How to cite this article: } \\
\text { Maleka, M.J., Paul-Dachapalli, } \\
\text { L.-A., Ragadu, S.C., Schultz, } \\
\text { C.M., \& Van Hoek, L. (2020). } \\
\text { Performance management, } \\
\text { vigour, and training and } \\
\text { development as predictors of } \\
\text { job satisfaction in low-income } \\
\text { workers. SA Journal of } \\
\text { Human Resource } \\
\text { Management/SA Tydskrif vir } \\
\text { Menslikehulpbronbestuur, } \\
\text { 18(0), a1257. https://doi. } \\
\text { org/10.4102/sajhrm. } \\
\text { v18i0.1257 }\end{array}$} \\
\hline \multicolumn{2}{|c|}{$\begin{array}{l}\text { Copyright: } \\
\text { (C) 2020. The Authors. } \\
\text { Licensee: AOSIS. This work } \\
\text { is licensed under the } \\
\text { Creative Commons } \\
\text { Attribution License. }\end{array}$} \\
\hline \multicolumn{2}{|l|}{ Read online: } \\
\hline 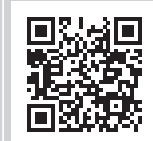 & $\begin{array}{l}\text { Scan this QR } \\
\text { code with your } \\
\text { smart phone or } \\
\text { mobile device } \\
\text { to read online. }\end{array}$ \\
\hline
\end{tabular}

Orientation: New insights into how managers can develop strategies to enhance job satisfaction, how researchers can use a different approach when collecting data by conducting a survey at a mall instead of an organisation, and an understanding of the relationship between performance management, vigour, and training and development of low-income workers form part of the orientation of this article.

Research purpose: The authors endeavoured to determine whether performance management, vigour, and training and development positively predicted the job satisfaction of low-income workers in the South African context.

Motivation for the study: Little, if any, research exists about the relationships between performance management, vigour, and training and development as well as the job satisfaction of low-income workers in the South African context.

Research approach/design and method: The research approach was quantitative, descriptive and causal in nature. This study mostly comprised the units of analysis, namely low-income workers who were under-researched in the South African context. Hence, 877 respondents were purposefully selected for this study.

Main findings: The results showed that performance management was the highest predictor of job satisfaction. The second highest predictor of job satisfaction was vigour, and the third highest predictor of job satisfaction was training and development.

Practical/managerial implications: This research will empower managers to develop strategies to enhance employees' job satisfaction by paying attention to performance management, vigour, and training and development.

Contribution/value-add: This study was conducted on an under-researched sample, at a mall and suggested vigour as an intrinsic variable to be included in the Herzberg job satisfaction model.

Keywords: performance management; vigour; training and development; job satisfaction; low-income workers.

\section{Introduction}

Job satisfaction can enhance the productivity of organisations. It is a salient construct to measure the human resource value chain (i.e. performance management, training and development, and talent management; Lee, 2011). Spector (1997) opines that to achieve job satisfaction, organisations should be guided by human values, primarily in terms of respect for and impartial treatment of employees, irrespective of their positions. Job satisfaction leads to positive employee behaviours, while job dissatisfaction results in negative behaviours (Amakiri \& Luke, 2015). Additionally, job satisfaction is one of the determinants of successful organisations.

For the purpose of this study, the focus was on performance management, training and development, as well as vigour, because these constructs are both extrinsic or external and intrinsic or internal (Herzberg, 1968). It was previously found that when employees were deprived of training opportunities, they tended to become disgruntled (Noland, 2014). In some instances, such employees even took the organisation to the dispute resolution body, lodged a grievance against the management or reported against the manager to trade union, arguing that it was an unfair labour practice (Bendix, 2015). In addition to being dissatisfied, employees who are not trained cannot perform optimally to assist organisations to achieve their strategic 
objectives (Amakiri \& Luke, 2015). According to the United Nations Human Development Report Office (2016, pp. 199), South Africa is ranked 119 of 188 countries 'which put the country in the medium human development category'. Research focusing on intrinsic satisfaction factors has revealed that in some cases, employees are engaged or have vigour when they work in organisations where managers do not treat them badly (Seymour \& Geldenhuys, 2018) and give them meaningful work (Kahn, 1990; Nienaber \& Martins, 2016) and interesting tasks (Bakker, 2017).

This is a salient study because it developed a job satisfaction model using the structural equation model (SEM) that can be used by managers who manage employees from the grey economy, or what Levy and Venter (2015) call non-core employees (i.e. part-time or casual employees). Previous job satisfaction studies using SEM and linear regression in the South African context focused on core employees working on permanent basis (Castro \& Martins, 2010; Maleka, Skosona, \& Lekgothoane, 2016). Hence, the research question for this study is as follows: Are performance management, vigour, and training and development predictors of low-income workers' job satisfaction?

According to the Tshwane Research Unit (2013), the population of Tshwane was 2.4 million, almost $40 \%$ of whom were low-income workers who commute via metro rail. Because of the exodus of prominent businesses and trade from the inner city, many smaller and informal businesses have exploded, thereby attracting low-income consumers and creating low-income jobs. Historically, most employees in South Africa were not earning living wages because they were not part of collective agreements (Statistics South Africa, 2014) whose implementation was associated with profit reduction (Moll, 1993).

\section{Purpose of the study}

Little, if any, research exists on the relationships between performance management, vigour, and training and development as well as the job satisfaction of low-income workers in the South African context. This is a research gap, and the purpose of this study was therefore to determine whether performance management, vigour, and training and development positively predicted the job satisfaction of low-income workers in the South African context.

\section{Theoretical framework and hypotheses development}

Job satisfaction is an employee's attitude towards, or how he or she is affected by, working conditions or experiences in the workplace (Alessandri et al., 2012; Locke, 1976). Herzberg's (1968) two-factor theory of job satisfaction discusses extrinsic (e.g. performance management and training and development) and intrinsic (e.g. vigour) satisfaction factors. According to Herzberg (1968), intrinsic factors are known as motivation factors, while extrinsic factors are known as hygiene factors. He conducted a study on accountants and engineers who earned high wages and concluded that hygiene factors are temporary and are therefore not satisfiers. The next discussion is on the predictors of job satisfaction, namely performance management, training and development, and vigour.

\section{Performance management as a predictor of job satisfaction}

For the purpose of this study, performance management focuses on an individual low-income worker. The purpose of performance management is to transmute the latent potential of an employee into performance by eliminating intermediate barriers to motivate employees to perform well for the achievement of shared goals (Da Silva Gomes, 2016; Nel, Kirsten, Swanepoel, Erasmus, \& Jordan, 2017). Performance management includes activities which guarantee that goals are consistently being met in an effective and efficient manner (Mathur \& Prasad, 2014).

Over 50 years ago, Herzberg (1968) spread awareness that when employees are satisfied with their jobs, they will perform well. Judge, Thoresen, Bono and Patton (2001) reviewed the literature available on this topic and presented a qualitative and quantitative evaluation of the relationship between job satisfaction and job performance from about 312 studies. Their qualitative results were inconsistent with regard to the satisfaction-performance relationship. Similarly, Bowling's (2007) study results were inconclusive as to whether performance predicted job satisfaction. On the other hand, Fisher's (2003) as well as McPherson and Wang's (2017) research revealed that employees who were performing well were more likely to be satisfied.

Therefore, the first hypothesis of this study can be stated as follows:

$\mathrm{H}_{1}$ : Performance management predicts job satisfaction.

\section{Vigour and job satisfaction}

Vigour represents the extent to which employees engage in their work proactively, take initiative (Chan, 2019) and are optimistic about their work (Schaufeli \& Bakker, 2010). It should be noted that vigour does not appear in Herzberg's (1968) original two-factor model (Busari, Mughal, Khan, Rasool, \& Kiyani, 2017). In this article, we argue that it is an intrinsic factor because it is about vitality, high levels of energy and mental resilience (Russell, 2003; Schaufeli \& Bakker, 2010) and vivacity (Shirom, 2003). Performance management, on the other hand, is an extrinsic factor. Previous research in South Africa on low-income workers has revealed that they work under appalling working conditions (Finnemore, 2009), are paid slave wages (Bendix, 2010), work in insecure jobs and are not unionised (Yu \& Roos, 2018). Hence, they must have high mental strength and be motivated to enhance their satisfaction levels. In line with this accession, international research conducted on middleincome workers has revealed that invigorated employees are satisfied (De Simone et al., 2014; Gillet, Huart, Colombat, \& 
Fouquereau, 2013; Macey \& Schneider, 2008; Salanova, Llorens, \& Schaufeli, 2011; Silman, 2014; Vansteenkiste et al., 2007) and stay with their organisations (Saks, 2006). Conversely, disengaged employees do not perform optimally (Rayton, Dodge, \& D'Analeze, 2012; Ruhlman \& Siegman, 2009) because they have low satisfaction levels (Yasin, Fernando, \& Caputi, 2013). Yalabik, Popaitoon, Chowne and Rayton (2013) and Barnes and Collier (2013) opine that satisfaction with various job aspects is important for employees to become invigorated. Usually, high-skilled, selfemployed workers report higher levels of work engagement than workers employed with organisations (Bujacz, Bernhard-Oettel, Rigotti, \& Lindfors, 2017).

Hence, the second hypothesis of this study is as follows:

$\mathrm{H}_{2}$ : Vigour positively predicts job satisfaction.

\section{Training and development and job satisfaction}

The other extrinsic factor related to employees' satisfaction is training and development (Allen, Shore, \& Griffeth, 2003; Bakar, 2011; Chaudhary \& Bhaskar, 2016; Samuel \& Chipunza, 2009; Schmidt, 2007; Smit \& Cronje, 2002). Erasmus, Loedolff, Mda and Nel (2015) define training as 'Training and development is defined as a "planned acquisition of knowledge, skills and abilities to carry out a specific task or job in a particular setting" Erasmus, Loedolff, Mda and Nel (2015, pp. 20).' Employees who are trained enable workplaces to become competitive (Van Aswegen, 2012). In a survey of employees in the United States and Canada, $80 \%$ of the respondents indicated that training was a vital factor in their jobs because it increased their skills and abilities (Community Banker, 2001). Research conducted amongst 575 IT professionals found that dissatisfied employees attributed their discontentment to their inability to have training they wanted (Melymuka, 2000).

The commonality between Melymuka's (2000) and Van Aswegen's (2012) studies is that they conducted their research in 'big-budget' organisations. The low-income workers in Marabastad, where previous research was conducted, revealed that work in retail and wholesale economic sectors had low budgets for training. Zeytinoglu, Cooke, Harry and Chowhan (2008) indicate that internationally, workers in lower-paid jobs have less opportunity for training compared to workers in higher-paid jobs. Organisations that can afford to train employees have the benefit that they manage to retain their employees (Wagner, 2000). Such organisations include training, which is one of Herzberg's extrinsic factors, as a benefit (Maleka, 2012). Organisations providing training and development programmes for their employees are able to achieve higher levels of employee satisfaction and have lower attrition rate (Salas, Burke, Bowers, \& Wilson, 2001).

Hence, the third hypothesis of this study can be stated as follows:

$\mathrm{H}_{3}$ : Training and development positively predicts job satisfaction.
In the next section, the research approach, respondents, measuring instrument, procedure and statistical analysis are discussed.

The conceptual model is displayed in Figure 1.

\section{Methods \\ Research approach}

The research approach that was deemed appropriate for this study was quantitative, descriptive and correlational in nature (Bless, Higson-Smith, \& Sithole, 2013) because the researchers intended to quantify and measure the relationships between performance management, vigour, and training and development, as well as the job satisfaction, of low-income workers.

\section{Procedure}

The authors were given permission by the university to collect data and were advised to act ethically when collecting the data. The instrument was presented to human resource management experts (Spector, 2012) and pre-tested on 20 respondents in March 2016 to ensure that the questionnaire measured what it was intended to measure. Participation in the study was voluntary, and respondents were informed that they could withdraw from the study if they felt uncomfortable about participating. Furthermore, in order to ensure that respondents' identities were kept confidential and anonymous, their names were not written on the instruments when they participated in the study (Bless et al., 2013).

\section{Measuring instrument}

In addition to biographical variables, the measuring instrument contained the following measuring scales: vigour (Schaufeli, Salanova, Gonzalez-Roma, \& Baker, 2002), performance management, training and development (Van Hoek, 2014) and job satisfaction (Spector, 1985). Performance management, job satisfaction, and training and development were measured on a five-point Likert scale ( 1 = strongly disagree to $5=$ strongly agree). Vigour was measured on a seven-point Likert scale $(0=$ never to $6=$ always $)$. In Table 3 ,

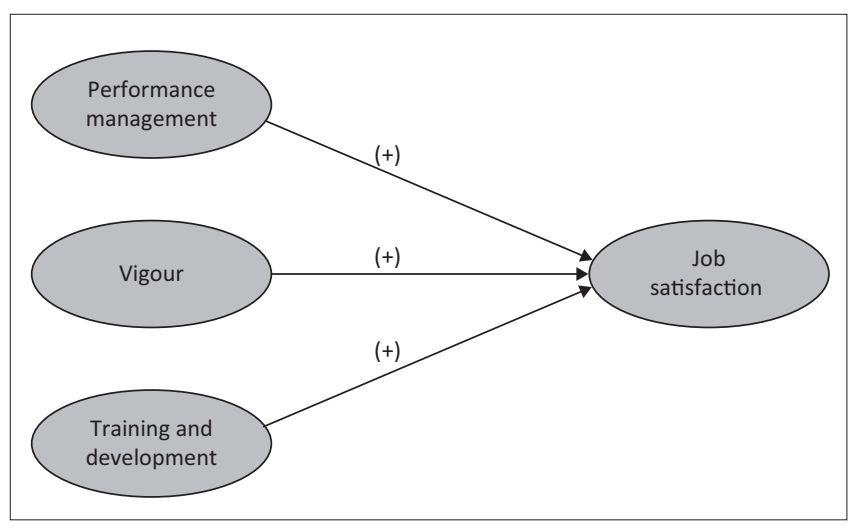

Source: Adapted from Lee, G.J. (2011). HR metrics: Strategic and quantitative tools for people management. Randburg: Knowres.

FIGURE 1: Performance management, vigour, and training and development. 
the average variance extracted (AVE) scores were above 0.5, suggesting that convergent validity was achieved. To determine discriminant validity, the researchers followed the criteria proposed by Fornell and Larcker (1981), who state that there must be a correlation between the off-diagonal values and latent variables. The composite reliability (CR) values showed that the model was reliable, and the Cronbach's alpha values showed that the variables were reliable because it was above the threshold value of 0.7 as suggested by Maree (2016).

\section{Statistical analysis}

Statistical analysis was conducted using Amos version 25. The authors followed the guidelines for model fit indexes provided by Hair, Black, Babin and Anderson (2014). The following results were obtained: Chi-squared $\left(\chi^{2}\right)=p \leq 0.05$, root mean square error (RMSEA) $\leq 0.07$, comparative fit index $(\mathrm{CFI}) \geq 0.90$, goodness of fit index $(\mathrm{GFI}) \geq 0.90$ and Tuckey-Lewis Index (TLI) $\geq 0.90$. Construct validity was achieved by retaining factor loadings above a cut-off value of 0.3 (Field, 2018) and by calculating AVE (Maleka, Mmako, \& Swartz, 2017). Structural equation model was conducted to test the hypotheses (Byrne, 2010; Castro \& Martins, 2010; Maleka et al., 2017). Hair et al. (2014) suggest that a sample size of 500 is appropriate to conduct SEM.

\section{Results}

In this section, descriptive and inferential statistics are discussed.

\section{Descriptive statistics}

\section{Respondents}

The research site was situated in Marabastad Mall in Gauteng, South Africa. This mall is usually visited by lowincome workers, but unfortunately the population size could not be determined. The respondents were selected using convenience sampling because the researchers did not have access to a sampling frame (Leedy \& Ormrod, 2015; Neuman, 2014). A total of 877 respondents participated in the study, and the response rate was $87.70 \%$, since $N=1000$ questionnaires were distributed. The response rate was therefore much higher than the $10 \%$ recommended in literature (Bless et al., 2013). The data presented in Table 1 show that more female participants $(51.80 \%)$ than male participants participated in the study and that $72.30 \%$ of the respondents were full-time employees. The focus of the study was not on non-core employees $(27.70 \%)$ but on core employees $(72.30 \%)$; however, for the completeness of the study, we decided to include non-core employees as well to have a holistic view of participants and their views. The majority of respondents $(27.20 \%)$ had qualifications ranging from grade 12 to a degree. Most of the respondents $(89.20 \%)$ were aged between 25 and 54 years. In total, $588(67.00 \%)$ respondents were not unionised, and $21.60 \%$ of the respondents lived in a household with two to six members.
TABLE 1: Distribution of respondents.

\begin{tabular}{|c|c|c|}
\hline Variable & Frequency $(n)$ & Percentage $(\%)$ \\
\hline \multicolumn{3}{|l|}{ Gender } \\
\hline Male & 420 & 47.90 \\
\hline Female & 454 & 51.80 \\
\hline Missing & 3 & 0.03 \\
\hline \multicolumn{3}{|l|}{ Employment status } \\
\hline Full-time & 620 & 72.30 \\
\hline Part-time & 238 & 27.70 \\
\hline \multicolumn{3}{|l|}{ Educational levels } \\
\hline Less than grade 12 & 222 & 26.10 \\
\hline Grade 12 & 238 & 27.20 \\
\hline Diploma & 165 & 18.90 \\
\hline Degree & 139 & 15.90 \\
\hline Postgraduate & 75 & 8.60 \\
\hline Other & 30 & 3.4 \\
\hline \multicolumn{3}{|l|}{ Age } \\
\hline $18-24$ years & 75 & 8.60 \\
\hline $25-34$ years & 310 & 35.50 \\
\hline $35-44$ years & 344 & 39.40 \\
\hline $45-54$ years & 125 & 14.30 \\
\hline $55-65$ years & 20 & 2.30 \\
\hline \multicolumn{3}{|l|}{ Trade union } \\
\hline Yes & 280 & 31.90 \\
\hline No & 588 & 67.00 \\
\hline Missing & 9 & 1.00 \\
\hline \multicolumn{3}{|l|}{ Household number } \\
\hline One person & 76 & 8.70 \\
\hline Two persons & 103 & 11.80 \\
\hline Three persons & 157 & 18.00 \\
\hline Four persons & 180 & 20.50 \\
\hline Five persons & 167 & 19.00 \\
\hline Six persons & 189 & 21.60 \\
\hline Missing & 5 & 0.06 \\
\hline
\end{tabular}

On average, the respondents earned R7063.06 per month, which is within the low-income workers' minimum wage range of R4500 to R10 000, as suggested by Maleka et al. (2016). The average earning was above R3500, the suggested national minimum earnings in South Africa.

As observed in Table 2, the performance management (PM) mean scores were just above the mid-point of 3, suggesting a moderate positive trend. In addition, a positive trend was observed with the training and development (TD) and job satisfaction (JS) items, with the exception of the following item: 'I have a mentor that assists me with work-related matters' (mean $[M]=2.97$, standard deviation [SD] = 1.56). The following JS items had a reverse score: 'When I do a good job, I don't receive the recognition for it that I should receive' and 'I don't feel like the work I do is appreciated'.

\section{Measurement model}

The correlations between independent variables or exogenous constructs (i.e. TD, PM and vigour) were less than 0.7; hence, it can be argued that the assumption of multicollinearity was not violated (Pallant, 2016). As mentioned previously, the AVE scores were above 0.5, suggesting that convergent validity was achieved. The CR 
values showed that the model was reliable, and the Cronbach's alpha showed that the variables were reliable because it was above the threshold value of 0.7 as suggested by Maree (2016).

The data displayed in Figure 2 and Table 3 showed the correlations between predictors and JS. The data showed positive relationships between TD and PM $(r=0.59$, large effect), vigour and PM ( $r=0.65$, large effect), vigour and JS $(r=0.55$, large effect), PM and JS ( $r=0.55$, large effect), and TD and JS ( $r=0.31$, medium effect). All relationships were significant at the 0.05 level. The data displayed in Figure 2 showed that the model was a good fit $\left(\chi^{2}\right)(70)=258.68$, $p=0.00$. According to Hair et al.'s (2014) criteria, RMSEA = $0.06, \mathrm{CFI}=0.93, \mathrm{GFI}=0.91$ and $\mathrm{TLI}=0.92$.

The data presented in Figure 3 showed that both performance management $(\beta=0.36, p<0.05)$ and vigour $(\beta=0.33, p<0.05)$ positively predicted job satisfaction. Lastly, the data indicated that TD negatively predicted job satisfaction $(\beta=-0.04$, $p<0.05)$. Performance management was the highest predictor of job satisfaction, and the job satisfaction equation was estimated as follows:

$Y^{\prime}($ job satisfaction $)=0.36($ performance management $)+0.33$ (vigour) -0.04 (training and development).

TABLE 2: Descriptive statistics.

\begin{tabular}{|c|c|c|c|c|c|c|}
\hline \multirow[t]{2}{*}{ Items description } & \multirow{2}{*}{$\frac{\text { Mean }(M)}{\text { Statistic }}$} & \multirow{2}{*}{$\frac{\text { Std. deviation (SD) }}{\text { Statistic }}$} & \multicolumn{2}{|c|}{ Skewness } & \multicolumn{2}{|c|}{ Kurtosis } \\
\hline & & & Statistic & Std. error & Statistic & Std. error \\
\hline I receive relevant feedback on my performance (PM3) & 3.18 & 1.39 & -0.14 & 0.08 & -1.18 & 0.17 \\
\hline $\begin{array}{l}\text { I am satisfied with the way in which the organisation applies its performance management } \\
\text { system (PM2) }\end{array}$ & 3.01 & 1.44 & -0.01 & 0.08 & -1.30 & 0.17 \\
\hline Areas of skills development are effectively identified and communicated to me (PM1) & 3.20 & 1.44 & -0.20 & 0.08 & -1.28 & 0.17 \\
\hline I can continue working for very long periods at a time (VI3) & 3.33 & 1.79 & -0.17 & 0.08 & -0.57 & 0.17 \\
\hline When I get up in the morning, I feel like going to work (VI2) & 3.52 & 1.63 & -0.19 & 0.08 & -0.230 & 0.167 \\
\hline At my work, I feel that I am bursting with energy (VI1) & 3.41 & 1.70 & -0.14 & 0.08 & -0.439 & 0.167 \\
\hline The organisation provides opportunities for further training and development (TD1) & 3.22 & 1.47 & -0.18 & 0.08 & -1.347 & 0.166 \\
\hline The organisation contributes financially to training and development (TD2) & 3.07 & 1.52 & -0.02 & 0.08 & -1.52 & 0.17 \\
\hline I have a mentor who assists me with work-related matters (TD3) & 2.97 & 1.56 & 0.04 & 0.08 & -1.524 & 0.17 \\
\hline My supervisor is not quite competent in doing his/her job (Rec_SS1) & 3.68 & 1.30 & -0.75 & 0.08 & -0.50 & 0.17 \\
\hline My supervisor is unfair to me (Rec_SS2) & 3.65 & 1.27 & -0.63 & 0.08 & -0.64 & 0.17 \\
\hline My supervisor shows little interest in the feelings of subordinates (Rec_SS3) & 3.47 & 1.30 & -0.51 & 0.08 & -0.756 & 0.17 \\
\hline When I do a good job, I don't receive the recognition for it that I should receive (Rec_RS1) & 3.17 & 1.33 & -0.07 & 0.08 & -1.104 & 0.17 \\
\hline I don't feel like the work I do is appreciated (Rec_RS1) & 3.15 & 1.32 & -0.07 & 0.08 & -1.07 & 0.17 \\
\hline
\end{tabular}

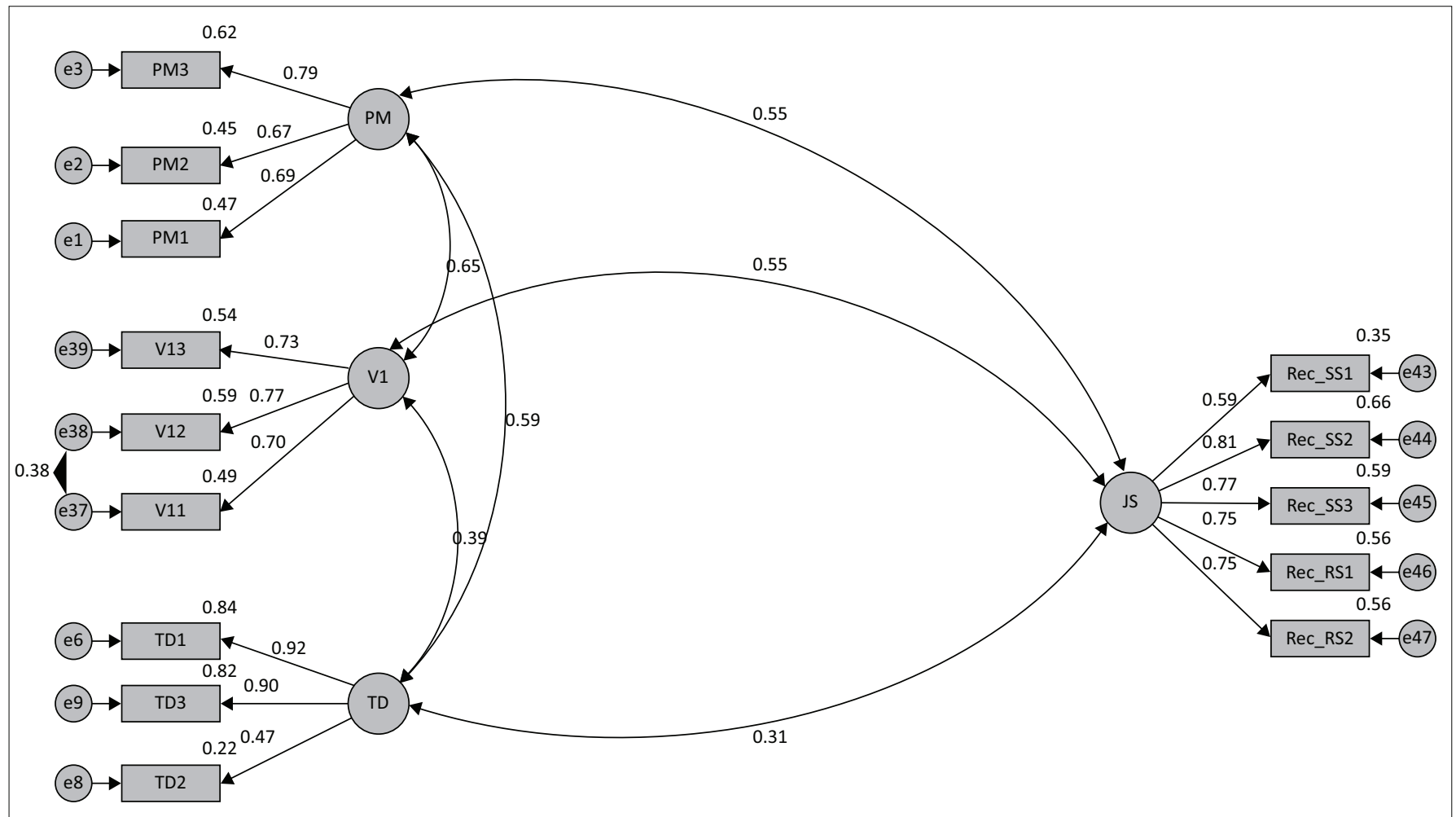

FIGURE 2: Measurement model. PM, performance management; VI, vigour; TD, training and development; JS, job satisfaction. 


\section{Discussion}

The purpose of the study was to determine the relationship between the job satisfaction of low-income workers in relation to performance management, vigour, and training and development. This study made a methodological contribution. Unlike other studies in South Africa and Africa on job satisfaction where data were collected in the workplace (Hansen, Buitendach, \& Kanengoni, 2015; Mitonga-Monga, Flotman, \& Cilliers, 2018), this study was conducted with low-income workers of a mall, as carried out in Canada (Zeng \& Honig, 2017).

The second contribution of the study was that it tested paths from an under-researched sample. Consistent with international research (Fisher, 2003), the results showed that performance management positively predicted job satisfaction. This means that employees will be content when they are given positive feedback, appraised fairly and recognised for their performance (Griffin, Phillips, Gully, \& Carrim, 2019). Surprisingly, the data on the SEM model showed that training and development did not positively predict job satisfaction,

TABLE 3: Correlations, average variance extracted, composite reliability and Cronbach's alpha values.

\begin{tabular}{lcccccccc}
\hline Variable & TD & PM & VI & JS & $\begin{array}{c}\text { Loading: } \\
\text { Min-max }\end{array}$ & AVE & CR & $\begin{array}{c}\text { Cronbach's } \\
\text { alpha }\end{array}$ \\
\hline TD & $\mathbf{0 . 7 9}$ & - & - & - & $0.47-0.92$ & 0.627 & 0.83 & 0.76 \\
PM & 0.59 & $\mathbf{0 . 7 2}$ & - & - & $0.69-0.79$ & 0.513 & 0.76 & 0.76 \\
VI & 0.39 & 0.65 & $\mathbf{0 . 7 3}$ & - & $0.70-0.77$ & 0.538 & 0.78 & 0.80 \\
JS & 0.31 & 0.55 & 0.55 & $\mathbf{0 . 7 4}$ & $0.59-0.77$ & 0.545 & 0.86 & 0.85 \\
\hline
\end{tabular}

Note: All the correlations scores were significant at $p 0.05$.

AVE, average variance extracted; $C R$, composite reliability; TD, training and development; $\mathrm{PM}$, performance management; $\mathrm{VI}$, vigour; JS, job satisfaction. $p \leq 0.05$. despite the measurement model showing a positive and significant relationship ( $r=0.31$, medium effect). This is known as a negative suppression effect (Kline, 2011). Schmidt (2007) found a strong positive relationship between training and job satisfaction. Lowry, Simon and Kimberley (2002) and Traut, Larsen and Fiemer (2000) also found a positive relationship between training and development and job satisfaction. Organisations that offer valuable and effective training have more satisfied and committed employees (Bartlett, 2001; Tansky \& Cohen, 2001). Employees who are satisfied with their jobs are willing to accept organisational goals and values, tend to be more motivated (Jalajas \& Bommer, 1999), are willing to exert effort in the workplace and are likely to stay in the organisation (Laschinger, Finegan, \& Shamian, 2001). It can be argued that the constructs used to test path relationships were valid and reliable. All the predictors had factor loadings from 0.47 to 0.67 , and Hair et al. (2014) opine that such loadings, AVE scores above 0.5 and Cronbach's alpha above 0.7 show that construct validity has been achieved and the constructs are unidimensional.

Thirdly, this study made a theoretical contribution by establishing that vigour is an intrinsic factor that was not originally included in Herzberg's two-factor model (Refer to Figure 3). Earlier, it was argued that South African low-income

TABLE 4: Hypothesis testing.

\begin{tabular}{lll}
\hline Hypothesis & Description & Decision \\
\hline $\mathrm{H}_{1}$ & $\begin{array}{l}\text { Performance management predicts } \\
\text { job satisfaction }\end{array}$ & Accepted \\
$\mathrm{H}_{2}$ & $\begin{array}{l}\text { Vigour positively predicts job } \\
\text { satisfaction }\end{array}$ & Accepted \\
$\mathrm{H}_{3}$ & $\begin{array}{l}\text { Training and development positively } \\
\text { predicts job satisfaction }\end{array}$ & Not accepted \\
\hline
\end{tabular}

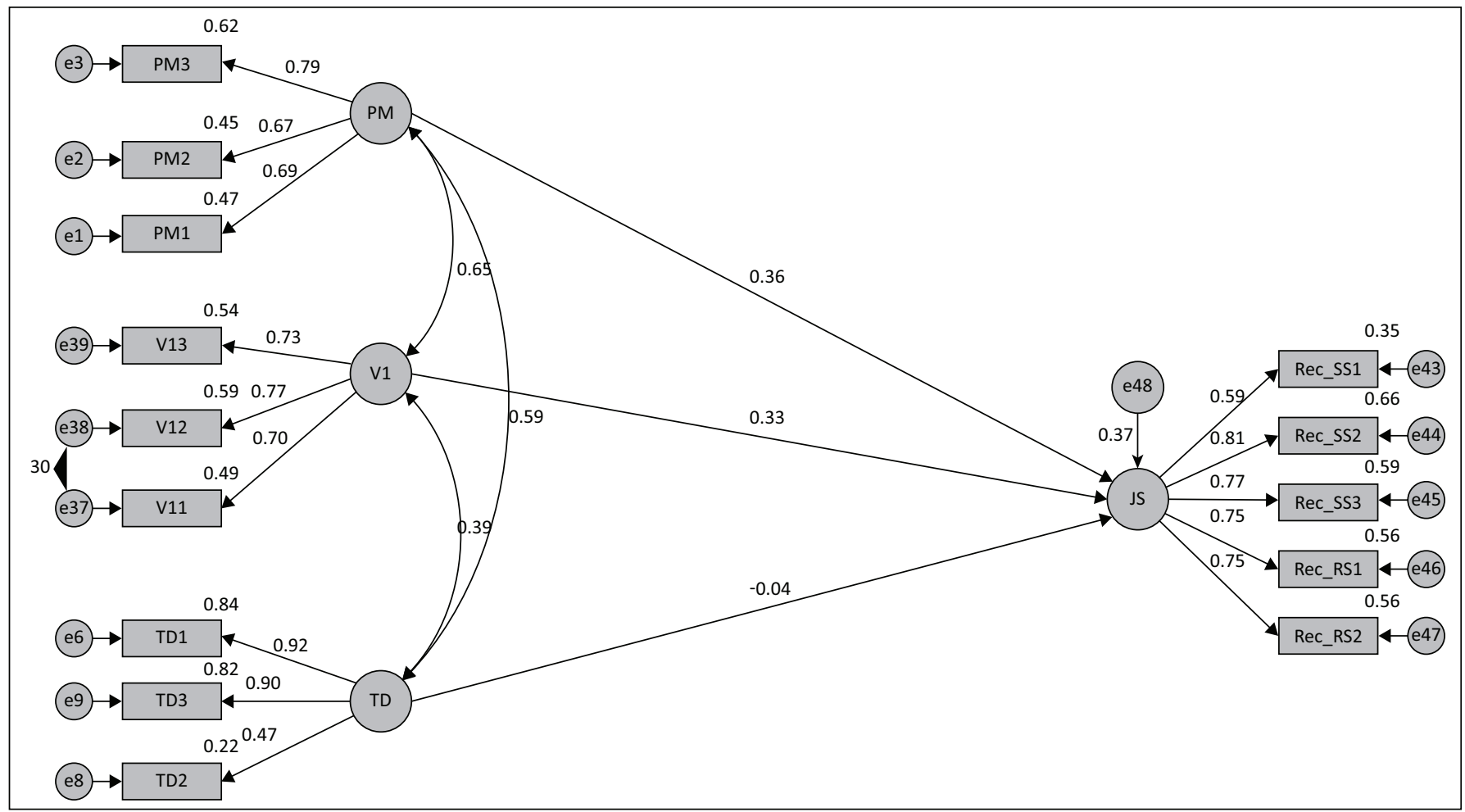

FIGURE 3: Structural model relationship between performance management (PM), vigour (VI), training and development (TD) and job satisfaction (JS). 
workers work under appalling working conditions, having insecure jobs and many are not unionised (Yu \& Roos, 2018). It is interesting to note that one of the vigour items, 'I can continue working for very long periods at a time', showed a negative trend $(M=3.33, \mathrm{SD}=1.79)$. Conversely, the other two vigour items, which related to bursting with energy $(M=3.41$, $\mathrm{SD}=1.70)$ and having positive feelings $(M=3.52, \mathrm{SD}=1.63)$, showed positive trends. This finding confirms the earlier argument made in this article that though low-income workers work under appalling working conditions (Finnemore, 2009), they invigorate themselves. Other scholars have opined that invigorated employees are mentally motivated (Russell, 2003; Schaufeli \& Bakker, 2010), are vivacious (Shirom, 2003), have high satisfaction levels (De Simone et al., 2014; Gillet et al., 2013), perform optimally (Rayton et al., 2012) and do not embark on counterproductive behaviour such as resignation (Saks, 2006). Similarly, the study results are consistent with the results of an international study which showed that high-income workers had high levels of engagement (Bujacz et al., 2017).

Figure 4 displays the intrinsic and extrinsic factors. The first two blocks are from Herzberg's original model. The third and fourth blocks are the ones that the authors of this article contribute to the discourse of Herzberg's theoretical framework. In this study, the data showed that low-income employees were invigorated even when they worked long hours and that they did not perceive training and development as having an effect on satisfaction. One of the logical factors is that in South Africa, there is a high unemployment rate (Bendix, 2015) and not coming to work being energised might have unintended consequences (e.g. being retrenched or dismissed for poor performance). Because majority of the respondents (460 out of 877 ) did not have post-matric qualifications, they can be easily replaced as they do not have specialised skills. The only attribute that they can bring to workplace is vigour. Moreover, 588 of 877 respondents were not unionised, suggesting that they were not protected.

\section{Practical implications}

It is crucial for the management to realise that they can influence the job satisfaction of low-income workers by addressing performance management, vigour, and training

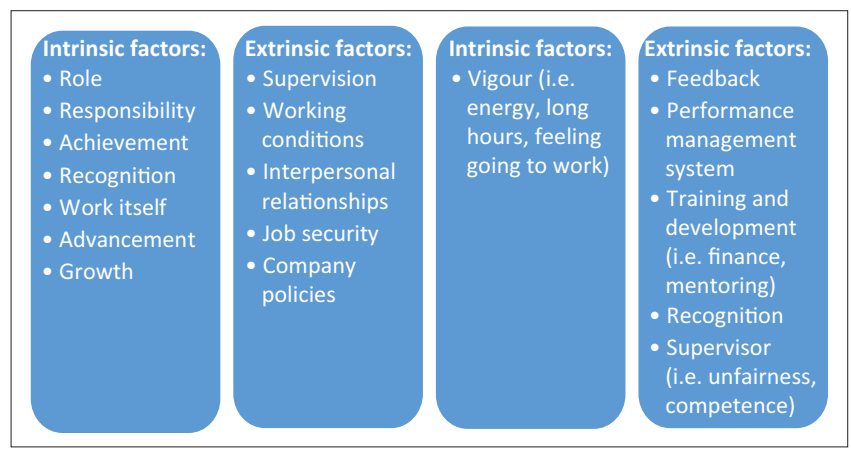

Source: Edrak, B.B., Yin-Fah, B.C., Gharleghi, B., \& Seng, T.K. (2013). The effectiveness of intrinsic and extrinsic motivations: A study of Malaysian Amway Company's direct sales forces. International Journal of Business and Social Science, 4(9), 96-103.

FIGURE 4: Intrinsic and extrinsic factors. and development. If these aspects are ignored, management will risk of having low-income workers who are not satisfied with their jobs. When the performance of low-income workers is managed effectively, it may enhance the success of organisations. The information gathered on performance management may lead to improved recruitment and selection (staffing) decisions and may assist in identifying the training and development needs of low-income workers. If organisations do not have sufficient training budget, they can rotate employees so that they gain more skills. For example, Ford Motor Company in Southern Africa trained low-income workers and moved from one to three shifts instead of opting for automation and gained more market share in the process (Ginindza, 2019). This is one of the many examples that showed that the industrial revolution does not always lead to job shedding; instead, if implemented in a humanistic way, it can create more jobs and revenue for the organisation.

Management should invest time in engaging with lowincome workers. One of the human resource management strategies to engage low-income workers is known as codetermination. Through co-determination, in a South African bus organisation in the North-West Province, Nienaber and Martins (2016) opined that low-income workers who were engaged felt satisfied, supported the organisation's strategy and assisted it to be profitable. Building healthy relationships with low-income workers is important, as trust is built and they become sincere towards management. If the management do not invest time in building these relationships and engaging with staff, they may face the risk of missing the heartbeat of an organisation. In 2012, when Lonmin, a mining company in Rustenburg, refused to engage low-income workers, it embarked on a long and violent unprotected strike and loss of revenue (Maleka, 2018). Issues such as vigour can be discussed, and ideas on how to improve vigour can be shared, as this helps to enhance job satisfaction.

Managers must invest time in the training and development of low-income workers and make them aware of better opportunities. These employees must be encouraged to attend available training and development initiatives. These training programmes are to form part of their personal development plans. In-house and/or external training and development opportunities can be introduced. If low-income employees are ignored, they may feel neglected and perceive that opportunities are only available for higher-income workers. Managers can therefore ill afford not to invest in the training and development of low-income workers.

\section{Recommendations}

The majority of respondents $(72.30 \%)$ in this study were fulltime employees, and hence, it is recommended that management should pay attention to the performance management, vigour, and training and development of these low-income workers in order to create an atmosphere in which they can have job satisfaction. Management should therefore give relevant feedback on the performance of 
low-income workers, as well as identifying areas of skills development for these workers. These employees should also receive recognition, because they want to feel appreciated in the workplace. Managers should engage with low-income workers with regard to their vigour, energy levels and ability to continue to work for long periods of time. Furthermore, organisations should make aware their employees of training and development opportunities as well as the funding available to attend training and development courses. Mentors can be introduced to assist low-income workers in their work-related matters. In order to enhance the job satisfaction of low-income workers, it is essential that the supervisor or direct manager be competent enough in doing his or her job, as well as showing an interest in the activities of these workers. Being fair towards workers is also important. It is recommended that three strategies should be developed by human resource specialists in conjunction with line management to ensure effective performance management, vigour as well as training and development of low-income workers. First, a strategy has to be developed to engage lowincome workers with human resource specialist to ensure they understand organisation's performance management as well as initiate interventions where needed. Second, in terms of vigour, a strategy (i.e. healthy eating habits, low consumption of sugar and physical exercise) should be developed to improve energy levels and workers' ability to work for long hours. Wellness experts should be consulted to ensure a holistic approach towards this end. Lastly, a strategy should be developed to link training and development with performance and rewards for low-income workers.

An alternative approach where the 'voices' of employees are explored qualitatively could supplement quantitative data to pave way for the future research. In addition, future research initiatives could focus on the evaluation research and the development of effective, uncomplicated and cost-effective performance management systems that include low-income employees. Overall, more studies related to low-income workers can be conducted in order to improve job satisfaction and productivity amongst these employees.

\section{Limitations}

One of the limitations of the study was that the authors did not have access to a sampling frame, and they, therefore, opted not to use probability sampling. Although the sample was big, the results could not be generalised for all low-income workers.

Low-income workers of only one mall participated in this study. This study consisted of a once-off snapshot and crosssectional design, with no causality tested. Furthermore, the industry and job categories of the participants were not investigated in this study.

\section{Conclusion}

The results of this study could help the management to realise the importance of investing in the performance management, vigour, and training and development of low-income workers in order to improve their job satisfaction. The study revealed a positive relationship between performance management and job satisfaction, as well as between vigour and job satisfaction. However, the relationship between training and development and job satisfaction was negative. Management should understand that they have the ability to inspire lowincome workers by evaluating their performance, giving proper feedback and encouraging them to attend training and development sessions. The realisation of the importance of vigour of these workers will also encourage managers to spend more time with them to create an energetic environment. The job satisfaction of low-income workers will then be positively affected. Lastly, more research should be conducted to obtain rich information about what motivates low-income workers and how their productivity can be increased.

\section{Acknowledgements}

The authors would like to thank Prof Stuart Carr from the Massey University, New Zealand, for acting as a mentor. He is the founding member of Global Living Organisational Wage.

\section{Competing interests}

The authors declare that they have no financial or personal relationships that may have inappropriately influenced them in writing this article.

\section{Authors' contributions}

All the authors were part of developing the measuring instrument. M.J.M. conceptualised this study, conducted the statistics and wrote the research methodology. Rest of the authors wrote the remaining article.

\section{Ethical consideration}

The proposal and questionnaire of the study were reviewed by a research ethics committee and an ethical clearance certificate (FREC2015/FR/09/020-MS) was granted.

\section{Funding information}

Tshwane University of Technology funded this research project.

\section{Data availability statement}

Data are available upon reasonable request from the author.

\section{Disclaimer}

The authors hereby declare that the article submitted for publication is their own work and has not previously been submitted to any other journal for publication.

\section{References}

Alessandri, G., Veccione, M., Tisak, J., Deiana, G., Caria, S., \& Caprara, G.V. (2012). The utility of positive orientation in predicting job performance and organisational citizenship behaviours. Applied Psychology: An International Review, 61(4), 1-30. https://doi.org/10.1111/j.1464-0597.2012.00511.x 
Allen, D.G., Shore, L.M., \& Griffeth, R.W. (2003). The role of perceived organizational support and supportive human resource practices in the turnover process. Journal of Management, 29(1), 99-118. https://doi.org/10.1177/014920630302900107

Amakiri, D., \& Luke, G.R. (2015). Job design and employee absenteeism: A case study of some government parastatals in Nigeria. International Journal of Secondary Education, 3(6), 67-71. https://doi.org/10.11648/j.ijsedu.s.2015030601.11

Bakar, A. (2011). The relationship between training and organisational performance through job satisfaction. International Journal of Industrial Engineering and Management Science, 1(1), 20-26.

Bakker, A.B. (2017). Strategic and proactive approaches to work engagement Organizational Dynamics, 46(2), 67-77. https://doi.org/10.1016/j.orgdyn.2017. 04.002

Barnes, D.C., \& Collier, J.E. (2013). Investigating work engagement in the service environment. Journal of Services Marketing, 27(6), 485-499. https://doi. org/10.1108/JSM-01-2012-0021

Bartlett, K.R. (2001). The relationship between training and organizational commitment: A study in the health care field. Human Resource Developmen Quarterly, 12(4), 335-352. https://doi.org/10.1002/hrdq.1001

Bendix, S. (2010). Industrial relations in South Africa. Cape Town: Juta.

Bendix, S. (2015). Labour relations: A Southern African perspective. Cape Town: Juta.

Bless, L., Higson-Smith, C., \& Sithole, S.L. (2013). Fundamentals of social research: An African perspective. Cape Town: Juta.

Bowling, N.A. (2007). Is the job satisfaction-job performance relationship spurious? A meta-analytic examination. Journal of Vocational Behavior, 71(2), 167-185. https://doi.org/10.1016/j.jvb.2007.04.007

Bujacz, A., Bernhard-Oettel, C., Rigotti, T., \& Lindfors, P. (2017). Task-level work engagement of self-employed and organizationally employed high-skilled workers. Career Development International, 2(6), 724-738. https://doi. org/10.1108/CDI-05-2016-0083

Busari, A.H., Mughal, Y.H., Khan, S.N., Rasool, S., \& Kiyani, A.A. (2017). Analytical cognitive style moderation on promotion and turnover intention. Journal of Management Development, 36(3), 438-464. https://doi.org/10.1108/JMD-12 2015-0184

Byrne, B.M. (2010). Structural equation modelling with Amos: Basic concepts, application, and programming. New York: Taylor \& Francis.

Castro, M.L., \& Martins, N. (2010). The relationship between organisational climate and employee satisfaction in a South African information and technology
organisation. South African Journal of Industrial Psychology, 36(1), 1-9. https:// organisation. South African Jour
doi.org/10.4102/sajip.v36i1.800

Chan, S.C.H. (2019). Participative leadership and job satisfaction: The mediating role of work engagement and the moderating role of fun experienced at work. of work engagement and the moderating role of fun experienced at work.
Leadership \& Organization Development Journal, 40(3), 319-333. https://doi. Leadership \& Organization Developr
org/10.1108/LODJ-06-2018-0215

Chaudhary, N.S., \& Bhaskar, P. (2016). Training and development and job satisfaction in education sector. International Journal of Business Quantitative Economics and in education sector. International Journal of Bus
applied Management Research, 2(8), 89-97.

Da Silva Gomes, J.F. (2016). Values, motivation, commitment, performance and rewards: Analysis model. Business Process Management Journal, 22(6), 11391169. https://doi.org/10.1108/BPMJ-09-2015-0132

De Simone, S., Lampis, J., Lasio, D., Serri, F., Cicotto, G., \& Putzu, D. (2014). Influences of work-family interface on job and life satisfaction. Applied Research in Quality of Life, 9(4), 831-861. https://doi.org/10.1007/s11482-013-9272-4

Edrak, B.B., Yin-Fah, B.C., Gharleghi, B., \& Seng, T.K. (2013). The effectiveness of intrinsic and extrinsic motivations: A study of Malaysian Amway Company's direct sales forces. International Journal of Business and Social Science, 4(9), 96-103.

Erasmus, B., Loedolff, P., Mda, T., \& Nel, P. (2015). Managing training and development (7th edn.). Cape Town: Oxford University Press.

Field, A. (2018). Discovering statistics using IBM SPSS Statistics (5th edn.). London: Sage.

Finnemore, M. (2009). Introduction to labour relations (10th edn.). Cape Town: LexisNexis.

Fisher, C.D. (2003). Why do lay people believe that satisfaction and performance are correlated? Possible sources of a common sense theory. Journal of Organizational Behavior, 24(6), 753-777. https://doi.org/10.1002/job.219

Fornell, C., \& Larcker, D.F. (1981). Evaluating structural equation models with unobservable variables and measurement error. Journal of Marketing Research, 18(1), 39-50. https://doi.org/10.1177/002224378101800104

Gillet, N., Huart, I., Colombat, P., \& Fouquereau, E. (2013). Perceived organizational support, motivation, and engagement among police officers. Professional Psychology: Research and Practice, 44(1), 46-55. https://doi.org/10.1037/ a0030066

Ginindza, B. (2019). Ford to create 1200 jobs as Silverton plant expands. Retrieved from https://www.iol.co.za/business-report/companies/ford-to-create-1200jobs-as-silverton-plant-expands-29401379

Griffin, R.W., Phillips, J.M., Gully, S.M., \& Carrim, N.M. (2019). Organisational behaviour Managing people and organisations (South African edn.). London: Cengage.

Hair, J.F., Black, W.C., Babin, B.J., \& Anderson, R.E. (2014). Multivariate data analysis. Harlow: Pearson.

Hansen, A., Buitendach, J.H., \& Kanengoni, H. (2015). Psychological capital, subjective well-being, burnout and job satisfaction amongst educators in the Umlazi region in South Africa. SA Journal of Human Resource Management, 13(1), a621. https:// doi.org/10.4102/sajhrm.v13i1.621
Herzberg, F. (1968). Work and the nature of man. London: Granada.

Jalajas, D.S., \& Bommer, M. (1999). The influence of job motivation versus downsizing on individual behaviour. Human Resource Development Quarterly, 10(4), 329-341. https://doi.org/10.1002/hrdq.3920100405

Judge, T.A., Thoresen, C.J., Bono, J.E., \& Patton, G.K. (2001). The job satisfaction-job performance relationship: A qualitative and quantitative review. Psychological Bulletin, 127(3), 376-407. https://doi.org/10.1037/0033-2909.127.3.376

Kahn, W.A. (1990). Psychological conditions of personal engagement and disengagement at work. Academy of Management Journal, 33(4), 692-724. https://doi.org/10.5465/256287

Kline, R.B. (2011). Principles and practice of structural equation modelling (3rd edn.). New York: Guildford.

Laschinger, H.K.S., Finegan, J., \& Shamian, J. (2001). The impact of workplace empowerment and organizational trust on staff nurses' work satisfaction and organizational commitment. Health Care Management Review, 26(3), 7-23. https://doi.org/10.1097/00004010-200107000-00002

Laseinde, O.T., \& Kanakana, G.M. (2017). In C.O. Ijagbemi \& H.M. Campbell (Eds.) Interventions to skills development in the automotive manufacturing sector of South Africa, skills development for sustainable manufacturing. IntechOpen. https://doi.org/10.5772/intechopen.70305. Retrieved from https://www. intechopen.com/books/skills-development-for-sustainable-manufacturing/ interventions-to-skills-development-in-the-automotive-manufacturing-sector-ofsouth-africa

Lee, G.J. (2011). HR metrics: Strategic and quantitative tools for people management. Randburg: Knowres.

Leedy, P.D., \& Ormrod, J.E. (2015). Practical research: Planning and design (11th edn.). Boston, MA: Pearson.

Levy, R., \& Venter, A. (2015). Labour relations in South Africa (5th edn.). Cape Town Oxford University Press.

Locke, E.A. (1976). The nature and causes of job satisfaction. In M.D. Dunnette (Ed.), Handbook of industrial and organisational psychology (pp. 1297-1349). Chicago, IL: Rand McNally.

Lowry, D.S., Simon, A., \& Kimberley, N. (2002). Toward improved employment relations practices of casual employees in the New South Wales registered clubs industry. Human Resource Development Quarterly, 13(1), 53-69. https://doi. org/10.1002/hrdq.1013

Macey, W.H., \& Schneider, B. (2008). The meaning of employee engagement. Industrial and Organizational Psychology, 1(1), 3-30. https://doi.org/10.1111/j. 1754-9434.2007.0002.x

Maleka, M.J. (2012). An in-depth investigation of the factors contributing to employee dissatisfaction at the Business Application Solution Centre (BASC), Eskom. Unpublished doctoral dissertation. Pretoria: UNISA.

Maleka, M.J. (2018). The biographical and human resource management predictors of union membership engagement of low- and middle-income workers. Journal of Economics and Behavioral Sciences, 10(1), 207-216. https://doi.org/10.22610/ jebs.v10i1.2103

Maleka, M.J., Mmako, M., \& Swarts, I. (2017). Antecedents of affective commitment of human resource management practitioners attending a professional body convention. Journal of Economics and Behavioral Sciences, 9(3), 121-132. https:// doi.org/10.22610/jebs.v9i3.1751

Maleka, M.J., Skosona, T.B., \& Lekgothoane, P.J. (2016). Work satisfaction of municipality employees while performing duties under the conditions of limited financial resources. Public and Municipal Finance, 5(3), 39-46. https://doi. org/10.21511/pmf.5(3).2016.05

Maree, K. (Eds). (2016). First steps in research (2nd edn.). Pretoria: Van Schaik.

Mathur, S., \& Prasad, R. (2014). Job Satisfaction a tool for performance management: A case study of a banking sector. International Journal of Management and International Business Studies, 4(2), 189-198.

McPherson, R., \& Wang, J. (2017). Low-income low-qualified employees' access to workplace learning. Journal of Workplace Learning, 26(6/7), 462-473. https://doi. org/10.1108/JWL-10-2013-0084

Melymuka, K. (2000, April 24). It's the opportunities, stupid. Computerworld. Retrieved from https://www.computerworld.com/article/2593928/it-s-theopportunities--stupid.html

Mitonga-Monga, J., Flotman, A., \& Cilliers, F. (2018). Job satisfaction and its relationship with organisational commitment: A Democratic Republic of Congo organisational perspective. Acta Commerciii, 18(1), a578. https://doi.org/10.4102/ organisational
ac.v18i1.578

Moll, P.G. (1993). Black South African unions: Relative wage effects in international perspective. Industrial and Labour Relations Review, 46(2), 320-335. https://doi. org/10.1177/001979399304600203

Nel, P.S., Kirsten, M., Swanepoel, B.J., Erasmus, B.J., \& Jordan, B. (2017). South African employment relations: Theory and practice (8th edn.). Pretoria: Van Schaik.

Neuman, W.L. (2014). Basics of social research: Qualitative and quantitative approaches (3rd edn.). Harlow: Pearson.

Nienaber, H., \& Martins, N. (Eds.). (2016). Employee engagement in a South African context. Randburg: KR Publishing.

Noland, C. (2014). Teaching Theory $X$ and Theory $Y$ in organisational communication. Communication Teacher, 28(3), 145-149. https://doi.org/10.1080/17404622.201 4.911333

Pallant, J. (2016). SPSS survival manual: A step-by-step guide to data analysis using IMB SPSS (6th edn.). Crows Nest, NSW: Allen \& Unwin. 
Rayton, B.A., Dodge, T., \& D'Analeze, S. (2012). Employee engagement: The evidence. Retrieved from https://engageforsuccess.org/employee-engagement-the-evidence

Ruhlman, J., \& Siegman, C. (2009, June 18). Boosting engagement while cutting costs. Gallup Management Journal. Retrieved from https://news.gallup.com/ businessjournal/120884/boosting-engagement-cutting-costs.aspx

Russell, J.A. (2003). Core affect and the psychological construction of emotion Psychological Review, 110(1), 145-172. https://doi.org/10.1037/0033-295X.110. 1.145

Saks, A.M. (2006). Antecedents and consequences of employee engagement. Journal of ManagerialPsychology,21(7),600-619.https://doi.org/10.1108/02683940610690169

Salanova, M., Llorens, S., \& Schaufeli, W.B. (2011). 'Yes, I can, I feel good, and I just do it!' On gain cycles and spirals of efficacy beliefs, affect, and engagement. Applied Psychology, 60(2), 255-285. https://doi.org/10.1111/j.1464-0597.2010.00435.x

Salas, E., Burke, C.S., Bowers, C.A., \& Wilson, K.A. (2001). Team training in the skies, does crew resource management (CRM) training work? Human factors. Journal of the Human Factors and Ergonomics Society, 43(4), 641-674. https://doi. the Human Factors and Ergonomich
org/10.1518/001872001775870386

Samuel, M.O., \& Chipunza, C. (2009). Employee retention and turnover: Using motivational variables as a panacea. African Journal of Business Management, 3(8), 410-415.

Schaufeli, W.B., \& Bakker, A.B. (2010). Defining and measuring work engagement: Bringing clarity to the concept. In A.B. Bakker \& M.P. Leiter (Eds.), Work engagement: A handbook of essential theory and research (pp. 10-24). New York: Psychology Press.

Schaufeli, W.B., Salanova, M., Gonzalez-Roma, V., \& Baker, A.B. (2002). The measurement of engagement and burnout: A confirmatory approach. Journal of Happiness Studies, 3(1), 71-92. https://doi.org/10.1023/A:1015630930326

Schmidt, S.W. (2007). The relationship between satisfaction with workplace training and overall job satisfaction. Human Resource Development Quarterly, 18(2), 4 https://doi.org/10.1002/hrdq.1216

Seymour, A.W., \& Geldenhuys, D.J. (2018). The impact of team dialogue sessions on employee engagement in an information and communication technology comploye engagement in an information and communication technology company. SA Journal of Human
org/10.4102/sajhrm.v16i0.987

Shirom, A. (2003). Feeling vigorous at work? The construct of vigor and the study of positive affect in organizations. In P.L. Perrewe \& D.C. Ganster (Eds.), Emotiona and physiological processes and positive intervention strategies (pp. 135-164). and physiological processes and positive intervention strategies
Retrieved from https://doi.org/10.1016/S1479-3555(03)03004-X

Silman, F. (2014). Work-related basic need satisfaction as a predictor of work engagement among academic staff in Turkey. South African Journal of Education, 34(3), 1-5. https://doi.org/10.15700/201409161119

Smit, P.J., \& Cronje, G. (2002). Management principles. Cape Town: Juta.

Spector, P.E. (1985). Measurement of human service staff satisfaction: Development of job satisfaction survey. American Journal of Community Psychology, 13(6) 693-713. https://doi.org/10.1007/BF00929796

Spector, P.E. (1997). Job satisfaction: Application, assessment, causes and consequences. Thousand Oaks, CA: Sage.
Spector, P.E. (2012). Industrial and organisational psychology: Research and practice (6th edn.). New York: Wiley.

Statistics South Africa. (2014). Quarterly labour force survey. Retrieved from http:// beta2.statssa.gov.za/publications/P0211/P02111stQuarter2014.pdf

Tansky, J.W., \& Cohen, D.J. (2001). The relationship between organizational support, employee development, and organizational commitment: An empirical study. Human Resource Development Quarterly, 12(3), 285-300. https://doi.org/10.1002/ hrdq. 15

Traut, C.A., Larsen, R., \& Fiemer, S.H. (2000). Hanging on or fading out. Public Personnel Management, 29(3), 343. https://doi.org/10.1177/009102600002900304

Tshwane Research Unit. (2013). City of Tshwane general and regional overview. Retrieved from http://www.parliament.gov.za/content/Tshwane_General_and Regions_Report_2013.pdf

United Nations Human Development Report Office. (2016). Briefing note for countries on the 2016 Human Development Report. Retrieved from http://hdr.undp.org/ sites/all/themes/hdr_theme/country-notes/ZAF.pdf

Van Aswegen, S. (2012). Introduction to human resource management: Fresh perspectives. Cape Town: Pearson.

Van Hoek, C.E. (2014). A competitive talent management strategy for a natural resources mining company in selected countries in Africa. Unpublished doctoral dissertation. Pretoria: Tshwane University of Technology.

Vansteenkiste, M., Neyrinck, B., Niemiec, C.P., Soenens, B., De Witte, H., \& Van den Broeck, A. (2007). On the relations among work value orientations, psychological need satisfaction and job outcomes: A self-determination theory approach. Journal of Occupational and Organizational Psychology, 80(2), 251-277. https:// doi.org/10.1348/096317906X111024

Wagner, S. (2000). Retention: Finders, keepers. Training and Development, 54(8), 64-72.

Community Banker. (2001). What drives employee satisfaction? Community Banker 10(7), 42.

Yalabik, Z.Y., Popaitoon, P., Chowne, J.A., \& Rayton, B.A. (2013). Work engagement as a mediator between employee attitudes and outcomes. The International Journal of Human Resource Management, 24(14), 2799-2823. https://doi.org/10.1080/0 9585192.2013.763844

Yasin, M., Fernando, M., \& Caputi, P. (2013). Transformational leadership and work engagement. Leadership and Organization Development Journal, 34(6), 532-550. https://doi.org/10.1108/LODJ-10-2011-0110

Yu, D., \& Roos, P. (2018). The South African labour market (6thedn.). Pretoria: Van Schaik.

Zeng, Z., \& Honig, B. (2017). Can a living wage be a win-win policy? A study of living wage effects on employer and employee performance in Hamilton. In R. Phillips \& C. Wong (Eds.), Handbook of community well-being research. Manchester: C. Wong

Zeytinoglu, I.U., Cooke, G.B., Harry, K., \& Chowhan, J. (2008). Low paid workers and on the job training in Canada. Industrial Relations, 63(1), 5-29. https://doi. org/10.7202/018120ar 